\title{
ANALISIS PERBANDINGAN KEPUASAN KONSUMEN ATAS PELAYANAN MINIMARKET INDOMARET DAN ALFAMART DI WILAYAH DUKUHWALUH (A VOMPARATIVE ANALYSIS OF COSTUMER STATIFACTION ON THE SERVICE OF INDOMARET AND ALFAMART MINIMARKET IN DUKUHWALUH)
}

\author{
Umiyati \\ Universitas Muhammadiyah Purwokerto \\ Suyoto \\ Universitas Muhammadiyah Purwokerto
}

\begin{abstract}
Abstrack
The aimost this research were: 1) to find out whether there was any difference on consumers stratification of indomaret and alfamart m,inimarket in Dukuhwaluh area. 2) to find out the differing factor on consumers stratification of indomaret and alfamart minimarket in Dukuhwalu area. This research used primary data gained from questionnaire. The data was analyzed by compare means independent $t$ test, descriptive analysis with SPSS program. The result of the research showed that the service quality of indomaret and alfamart minimarket was supposed to be good by most of their consumers. There was a significant difference in the comparison between indomaret and alfamart minimarket based on dimension of reliability, responsiveness, assurance, emphaty and tangible as well as the overall quality. Based on the $t$ test result of indomaret and alfamart, responsiveness dimension was regarded as the responsiveness dimension was not suitable as expected eiyher by the consumers of alfamart or the consumers indomaret. It indicated that it needs the betterment of service quality, specially in responsiveness dimension.

Keyword :consumers stratification, reliability, responsiveness, assurance, emphaty and tangible.
\end{abstract}

\section{PENDAHULUAN}

Pelayanan merupakan salah satu faktor penting ynag perlu diperhatikan oleh perusahaan termasuk minimarket Indomaret dan Alfamart yang ada di wilayah dukuhwaluh agar dapat memuaskan pelangganya. Untuk melakukan pelayanan tersebut tidak sematamata hanya menekankan pada aspek transaksi namunn justru berfokus pada aspek relational. Pelayanan menurut Kolter (2000) didefinisakan sebagai suatu tindakan atau kegiatan yang dapat ditawarkan oleh satu pihak ke pihak lain, pada dasarnya tidak berwujud dan mengakibatkan kepemilikan apapun. Dalam kamus besar bahasa Indonesia dijelaskan pelayanan sebagai usaha memenuhi kebutuhan orang lain, sedang melayani adalah membantu menyiapkan (mengurus) apa yang diperlukan seseorang.

Dimensi kualitas jasa dalam model servqual (service quality) didasarkan pada skala multi item yang dirancang untuk mengukur harapan dan presepsi pelangggan, serta gap diantara keduanya dalam dimensi-dimensi kualitas jasa. Pada awalnya parasuraman (1985) mengidentifikasi sepuluh dimensi pokok dengan 22 variabel yang berkaitan dengan pelayanan dan kemudian dianalisis dengan memakai analaisis faktor. Ternyata dapat ditemukan beberapa kriteria yang digunakan dalam menilai mutu pelayanan. Kriteria tersebut meliputi 10 dimensi potensial yang saling melengkapi yaitu tangibles, reliability, 
responivensess, communication, credibility, security, competence, courtesy, understanding, dan acces.

Kemudian pada penelitian selanjutnya Parasuraman et al ditahun 1988 menyempurnakan dimensi tersebut, kemudian diolah lagi sehingga hasilnya disederhanakan menjadi 5 dimensi yaitu: (a) Responsive (daya tanggap/kesigapan) adalah salah satu respon/kesigapan karyawan dalam membantu konsumen dan memberikan pelayanan yang cepat dan tanggap. (b) Reliability (keandalan) adalah suatu kemampuan untuk memberikan jasa yang dijanjikan dengan akurat dan terpercaya. (c) Assurance (jaminan) adalah kemampuan karyawan atas pengetahuan terhadap produk secara tepat, kulatias, keramahtamahan, perkataa atau kesopanan dalam memberikan pelayanan, keterampilan dalam memberikan informasi dan kemampuan dalam menanamkan kepercayaan konsumen/pelanggan terhadap perusahaan. (d) Emphaty (perhatian) adalaha kemampuan perusahaan dalam memberikan perhatian yang bersifat individual atau pribadi kepada para pelanggan/konsumen. (e) Tangibles (kemampuan fisik) adalah suatu bentuk penampilan fisik, peralatan personal, media komunkasi dan hal-hal yang lainya yang bersifat fisik.

Pada dasarnya kepuasan konsumen mencakup perbedaan antara tingkat kepentingan dan kinerja atau hasil yang dirasakan. Hakikatnya kepuasan konsumen merupakan evaluasi purna beli dimana alternatif yang dipilih sekurang-kurangnya dapat memberikan hasil (outcome) samaatau melampaui harapan konsumen, sedangkan ketidakpuasan dapat terjadi apabila hasil yang diperoleh tidak memenuhi harapan yang diinginkan konsumen. Jadi tingkat kepuasan merupakan fungsi dari perbedaan antara kinerja yang dirasakan oleh harapan, jika kinerja yang dirasakan di bawah harapan maka konsumen merasa tidak puas, sedangkan jka kinerja dirasakan melampaui harapan maka konsumen akan merasa sangat puas.

Kualitas pelayanan merupakan kinerja terpenting bagi kepuasan konsumen atau pelanggan. Perusahaan harus memperhatikan hal-hal penting bagi konsumen, supaya mereka merasakan kepuasan sebagaimana yang diharapkan. Masalah pelayanan bukan hal yang sulit atau rumit untuk dilakukan, tetapi apabila hal ini kurang diperhatikan maka dapat menimbulkan hal-hal yang rawan karena sifatnya yang sangat sensitif. System pelayanan perlu didukung oleh kualitas pelayanan, fasilitas yang memadai dan etika atau tata karma. Tujuan memberikan pelayanan adalah untuk memberikan kepuasan pada konsumen atau pelanggan, sehingga nilai tambah perusahaan meningkat.

Untuk itu peneliti merasa tertarik untuk melakukan penelitian perbandingan kepuasan konsumen toko tersebut mengapa hal tersebut dapat mempengaruhi penjualan padahal keduanya memiliki strategi pemasaran yang hampir sama dan pelayanan yang hampir sama juga adakah perbedaan pada keduanya yang pada akhirnya mempengaruhi citra toko dari kacamata konsumen, apakah yang membuat berhasil mewujudkan kesan yang baik pada pelanggan dan pada akhirnya akan memudahkan meraih konsumen.

Hasil penelitian sebelumnaya yang dilakukan oleh Elida (2009) pada analisis perbandingan kepuasankonsumen terhadap pelayanan pada minimarket Indomaret dan Alfamart dikompleks Pesona Anggrek Bekasi menunjukan bahwa kualitas pelayanan dari minimarket Indomaret dan Alfamart dinilai baik oleh sebagian besar pelanggannya. Sedangkan hasil uji perbandingna kualitas pelayanan antara minimarket Indomaret dan Alfamart berdasarkan dimensi kehandalan, keresponsifan, assurance, emphaty dan tangible serta kualitas pelayanan keseluruhan ada perbedaan yang signifikan.

\section{PERUMUSAN MASALAH}

Untuk mendapatka gambaran yang jelas mengenai masalah yang akan dibahas, yang nantinya digunakansebagai pedoman pembahasan yang lebih lanjut, rumusan masalah yang diambil adalah sebagai berikut : 
a. Apakah ada perbedaan signifikan kepuasan konsumen antara minimarket Indomaret dan Alfamart di wilayah Dukuhwaluh?

b. Apakah ada perbedaan signifikan dari segi kehandalan antara minimarket Indomaret dan Alfamart di wilayah Dukuhwaluh?

c. Apakah ada perbedaan signifikan dari segi ketanggapan antara minimarket Indomaret dan Alfamart di wilayah Dukuhwaluh?

d. Apakah ada perbedaan signifikan dari segi jaminan antara minimarket Indomaret dan Alfamart di wilayah Dukuhwaluh?

e. Apakah ada perbedaan signifikan dari segi perhatian antara minimarket Indomaret dan Alfamart di wilayah Dukuhwaluh?

f. Apakah ada perbedaan signifikan dari segi wujud antara minimarket Indomaret dan Alfamart di wilayah Dukuhwaluh?

\section{TUJUAN PENELITIAN}

Adanay tujuan penelitian ini adalah sebagai berikut:

a. Untuk membuktikan adanya perbedaan signifikan kepuasan konsumen antara minimarket Indomaret dan Alfamart di wilayah Dukuhwaluh.

b. Untuk membuktikan adanya perbedaan signifikan dari segi kehandalan antara minimarket Indomaret dan Alfamart di wilayah Dukuhwaluh.

c. Untuk membuktikan adanya perbedaan signifikan dari segi ketanggapan antara minimarket Indomaret dan Alfamart di wilayah Dukuhwaluh.

d. Untuk membuktikan adanya perbedaan signifikan dari segi jaminan antara minimarket Indomaret dan Alfamart di wilayah Dukuhwaluh.

e. Untuk membuktikan adanya perbedaan signifikan dari segi perhatian antara minimarket Indomaret dan Alfamart di wilayah Dukuhwaluh.

f. Untuk membuktikan adanya perbedaan signifikan dari segi wujud antara minimarket Indomaret dan Alfamart di wilayah Dukuhwaluh.

\section{TELAAH PUSTAKA}

\section{A. Penegertian Perilaku Konsumen}

Untuk memahami perilaku mansyarakat dalam pembelian barang dan jasa tersebut dibutuhkan studi tersendiri. Perusahaan berkepentingan dengan hampir setiap kegiatan manusia yang hanya dalam lingkup yang lebih terbatas. Perilaku konsumen sangat komplek dan sulit di prediksi. Pendekatan-pendekatan yang selama ini banyak digunakan untuk menyingkap sikap, minat, dan perilaku konsumen mengansumsikan bahwa konsumen bersikap rasional dalam setiap keputusan pembelian. Adapaun definisi perilaku konsumen adalah tindakan langsung terlibat dalam mendapatkan, mengkonsumsi, dan menghabiskan produk dan jas atermasuk proses keputusan yang mendahului dan menyusuli tindakan ini (Engel dan Blackwell, 1994).

\section{B. Pengertian Kepuasan Konsumen}

Kepuasan konsumen adalah perasaan seseorang yang puas atau sebaliknya setelah membandingkan antara kenyataan dan harapan yang diterima dari sebuah produk atau jasa (Kolter 2000). Kepuasan konsumen hanya dapat tercapai dengan memberikan pelayanan yang berkualitas kepada konsumenya. Pelayanan yang baik sering dinilai oleh konsumen secara langsung dari karyawan sebagai orang yang melayani atau disebut juga sebaga produsen jasa, karena itu diperlukan usaha untuk meningkatkan kualitas sistem pelayanan yang diberikan agar dapat memenuhi keinginan danmeningkatkan kepuasan konsumen. Jadi kualitas pelayanan merupakan hal penting yang harus diperhatikan oleh perusahaan agar dapat tercapai kepuasan konsumen. Kualitas pelayanan memiliki hubungan yang erat dengan

kepuasan konsumen. Kualitas memberikan suatu dorongan kepada konsumen untuk 
menjalin hubungan yang kuat dengan perusahaan. Dalam jangka panjang ikatan ini memungkinakan perusahaan untuk memahami dengan seksama harapan konsumen serta kebutuhanya.

Dengan demikian perusahaan dapat meningkatkan kepuasan konsumen dan pada giliranya kepuasan tersebut dapat menciptaka kesetiaan / loyalitas konsumen. Dengan tercapainya kualitas layanan yang sempurna akan mendorong terciptanya kepuasan konsumen karena kualitas layanan merupakan sarana untuk mewujudkan kepuasan konsumen. Kualitas layanan dapat diwujudkan dengan memberikan layanan kepada konsumen dengan sebaik mungkin sesuai dengan apa yang menjadi harapan konsumen. Kepuasan pada salah satu atau lebih dar dimensi layana tersebut tentuanya akanmemberikan kontribusi terhadap tingkat layanan secara keseluruhan, sehingga upaya untuk meningkatkan kualitas layanan untuk masing-masing dimensi layanan harus tetap menjadi perhatian.

\section{Pengertian Pelayanan}

Menurut Kolter (2000) pelayanan merupakan setiap tindakan atau kegiatan yang dapat ditawarkan oleh satu pihak kepada pihak lain, pada dasarnya tidak terwujud dan mengakibatkan kepemilikan apapun. Menurut Umar (2000) pelayanan secara umum adalah rasa menyenangkan yang diberikan kepada orang lain disertai kemudahan-kemudahan dan memenuhi segala kebutuhan mereka.

Menurut Payne (2000) pelayanan adalah rasa menyenangkan atau tidak menyenangkan yang oleh penerimapelayanan pada saat memperoleh pelayanan. Payne juga mengatakan bahwa pelayanan pelanggan mengandung pengertian:

a. Segala kegiatan yang dibutuhkan untuk menerima, memproses, menyampaikan dan memenuhi pesana pelanggan dan untuk menindak lanjuti setiap kegiatan yang mengandung kegiatan.

b. Ketepatan waktu dan reliabilitas penyampaina jasa kepada pelanggan sesuai dengan harapan mereka.

c. Serangkaian kegiatan yang meliputi semua bidang bisnis yang terpadu untuk menyampaikan produk-produk dan jasa tersebut sedemikian rupa sehingga dipersepsikan memuaskan oleh pelanggan dan merealisasikan pencapaian tujuan-tujuan perusahaan.

d. Total pesanan yang masuk dan seluruh komunikasi dengan pelanggan.

e. Penyampaian produk kepada pelanggan tepat waktu dan akurat dengan segala tindak lanjut serta tanggapan keterangan yang akurat.

D. Kualitas Jasa

Jasa adalah setiap kegiatan atau manfaat yang ditawarkan oleh suatu pihak pada pihak lain dan pada dasarnya tidak berwujud, serta tidak menghasilkan kepemilikan sesuatu. Proses produksinya mungkin dan mungkin juga tidak dikaitkan dengan suatu produk fisik (Kolter, 2000) menurut Parasuraman (Lupiyoadi, 2001) terdapat lima dimensi Servqual, yaitu:

a. Tangible (bukti fisik)

Kemampuan suatu perusahaan dalam menunjukan esistensinya kepada pihak eksternal. Penamilan dan kemampuan sarana dan prasarana fisik perusahaan dan keadaan lingkugan sekitarnya adalah bukti nyata dari pelayanan yang diberikan oleh pemberi jasa. Kinerja harus sesuai dengan harapan pelanggan yang berarti ketepatan waktu pelayanan yang sama untuk semua pelanggan.

b. Reliability (keandalan)

Kemampuan perusahaan untuk memberikan pelayanan sesuai dengan yang dijanjikan secara akurat dan terpercaya. Kinerja harus sesuai dengan harapan pelanggan yang berarti ketepatan waktu, pelayanan yang sama untuk semua pelanggan tanpa kesalahan, sikap yang simpatik, dan dengan akurasi yang tinggi.

c. Responsiveness (ketanggapan) 
Suatu kemampuan untuk membantu dan memberikan pelayanan yang cepat (responsive) dan tepat kepada pelnaggan denganpenyampaian informasi yang jelas. Membiarkan konsumen menunggu tanpa adanya suatu alasan yang jelas menyebabkan persepsi yang negatif dalam kualitas pelayanan.

d. Assurance (jaminan dan kepastian)

Penegtahuan, kesopansantunan dan kemampuan para pegawai perusahan untuk menumbuhkan rasa percaya para pelanggan kepada perusahaan. Terdiri dari beberapa komponen, antara lain komunikasi, kredibilitas, keamanan, kompetinsi dan sopan santun.

e. Emphaty (perhatian)

Memberikan perhatian yang tulus dan bersifat individual ata pribadi yang diberikan kepada para pelanggan denga berupaya memahami keinginan konsumen, dimana suatu perusahaan diharapkan memiliki pengertian da pengetahuan tentang pelanggan, memahami kebutuhan pelanggan secara spesifik, serta memiliki waktu pengoperasian bagi pelanggan.

\section{KERANGKA PEMIKIRAN}

Kualitas jasa yang baik merupakan hal yang sangat penting dalam menciptakan kepuasan pelanggan, namun untuk memahami bagaimana mengevaluasi kualitas yang diterima oleh konsumen tidaklah mudah. Kurtz dan Clow (1998) dalam Munawaroh (2000) menyatakan bahwa kualitas jasa lenih sukar untuk dievaluasi dibandingkan dengan kualitas barang. Keunggulan suatu produk jasa adalah tergantung dari keunikan serta kualitas yang diperhatikan oleh jasa tersebut, apakah sudah sesuai dengan harapan dan keinginana pelanggan atau konsumen (Dwiwinarsih, 2009).

Dalam menjalankan aktivitas bisnis atau kegiatan usahanya, umumnya yang harus diperhatikan perusahaan adalah orientasi pelanggan atau customer orientation yaitu menyangkut apa yang harus dipuaskan perusahaan terhadap pelanggan. Dengan lebih memperhatikan aspek tersebut tentunya tujuan yang ingin dicapai perusahaan akan dapat terwujud (Prasetyo, 2008). Walaupun memiliki berbagai produk layanan yang baik, namun semua hal diatas belum tentu membuat customer terpuaskan. Tingkat kepuasan customer sendiri tergantung pada kualitas pelayanan yang ditawarkan oleh perusahaan (Hermanto,2008). Kolter (2000) mendefinisikan kepuasan adalah tingkat perasaan seseorang setelah membandingkan kinerja (atau hasil) yang dirasakan dibandingkan dengan harapanya.

Menurut Kolter (1997) dalam Mulyono dkk (2008), suatu perusahaan dapat mengukur kepuasan pelangganya dengan berbagai cara, yakni: pertama, system keluhan dan saran (complaint dan suggestion system). Kedua, survey kepuasan pelanggan (customer satisfaction survey). Ketiga, pembeli bayangan (ghost shopping). Keempat, analisis pelanggan yang hilang (loss customer analysis).

Jika tingkat kepuasan merupakan fungsi dari perbedaan antara kinerja yang dirasakan oleh harapan,jika kinerja yang dirasakan dibawah harapan maka konsumen merasa tidak puas, sedangkan jika kinerja yang dirasakan sesuai dengan harapan maka niscaya konsumen merasa puas. Dan jika kinerja yang dirasakan melampaui harapan maka konsumen akan merasa sangat puas (Adi, 2008). Menurut Liu (2005) dalam Mulyono dkk, terdapat hubungan yang signifikan antara kepuasan konsumen dengan kualitas pelayanan di setiap tingkat pemisahan dari indikasi selanjutnya bahwa masing-masing sub divisi yaitu mengambil pengertian sebagai aspek penting dari kualitas pelayanan. andersson dan lindestad (1998) dalam Mulyono dkk, sengan studinya mengenai konsumen di Swedia membuktikan bahwa terdapat hubungan antara kualitas yang dirasakan dan kepuasan. Pelayanan yang berkinerja tinggi adalah pelayanan yang mampu melebihi harapan dari konsumen.

\section{METODE PENELITIAN}




\section{A. Metode Pengumpulan dan Pengukuran Data}

Pada penelitian ini penulis melakukan pengumpulan data, dengan cara :

Instrument kuesioner, dalam hal ini penulis menggunakan kuesioner untuk mengumpulkan data primer dalam bentuk pertanyaan tertutup, yaitu pertanyaan yang member kebebasan kepada responden untuk member jawaban, sebuah pertanyaan hanya bisa diberikan diantara pilihan yang suudah tersedia.

Sedangkan pengukuran data yag dilakukan oleh penukis yaitu menggunakan skala likert dengan criteria skor sebagai berikut :
1. Sangat Setuju (SS)
$=5$
2. Setuju (S)
$=4$
3. Ragu-Ragu (RR) = 3
4. Tidak Setuju (TS) $=2$
5. Sangat Tidak Setuju (STS) $=1$

Hasil dari pengumpulan dan pengukuran data tersebut akan diolah dengan program Statiscal Product and Service Solution (SPSS).

\section{B. Definisi Operasional Variabel}

\section{Kepuasan Konsumen}

Menurut Kolter (2001) kepuasan konsumen adalah sejauh mana anggapan kinerja produk memenuhi harapan pembeli. Bila kinerja produk lebih tinggi dibandingkan dengan harapan pelanggan, maka pembelinya merasa puas atau amat gembira. Indicator variable ini adalah:

a. Akan merekomendasikan kepada orang lain untuk berbelanja ditempat tersebut.

b. Akan melakukan pembelianulang.

c. Akan menjadi pelanggan setia.

d. Pelayanan yang diberika sesuai dengan harapan.

e. Pelayanan yang diberikan meningkatkan loyalitas dalam pembelian.

\section{Kualitas Pelayanan}

Menurut Kolter (2000) disimpulkan bahwa terdapat lima determinasi kualitas pelayanan sebagai berikut:

1. Reliability (kehandalan) adalah kemampuan untuk memberikan pelayanan dengan segera untuk memberikan kepuasan kepada pelanggan. Indikator variable ini adalah:

a. Karyawa memiliki komitmen untuk melayani konsumen, mereka akan melayani konsumen dengan baik.

b. Konsumen mendapatkan masalah, maka karyawan akan memberikan sikap sigap untuk menolong konsumenya.

c. Karyawan dapat diandalkan dan dipercaya dalam melayani konsumen.

d. Informasi yang dibuat selalu benar.

e. Pelayana yang ramah kepada konsumen.

2. Responsiveness (ketanggapan) adalah kemampuan untuk membantu pelanggan atua konsumen untuk memberikan pelayanan dengan cepat dan tanggap. Indikator variabel ini adalah:

a. Penyampaian informasi yang jelas tentang produk kepad akonsumen.

b. Pelayanan yang diberikan cepat.

c. Karyawan selalu bersedia untuk selalu membantu kesulitan yang dihadapi konsumenya. 
d. Karyawan bersedia meluangkan waktu untuk menggapai permintaan konsumen dengan cepat dan tepat.

3. Assurance (jaminan) adalah mencakup pengetahuan, kemampuan, kesopanan, dan sifat dapat dipercaya yang dimiliki para karyawan. Indikator variabel ini adalah:

a. Karyawan bersifat sabar, ramah dan sopan terhadap konsumen.

b. Konsumen merasa senang, aman dan nyaman ketika dilayani karyawan.

c. Perilaku karyawan dalam menjalankan pekerjaanya tidak mengganggu konsumen berbelanja.

d. Karyawan memiliki pengetahuan dan kemampuan yang cukup sesuai dengan bidang pekerjaanya.

e. Kesungguhan karyawan untuk tidak membanding-bandingkan konsumen.

4. Emphaty (perhatian) adalah kesediaan untuk kepedulian, memberikan perhatian pribadi pad apelanggan, Indikator variabel ini adalah:

a. Karyawan dapat memahami kebutuhan dan keinginan konsumenya.

b. Karyawan dapat memuaskan konsumen dalam memenuhi kebutuhan dan keinginanya.

c. Karyawan memberikan perhatian individual atau personal kepada konsumenya.

d. Karyawan memberikan keiuwesan atau kesesuaian jam kerja sesuai dengan kesibukan atau kebutuhan konsumen.

e. Kesungguhan dalam memperhatikan kepentingan konsumen.

5. Tangible (berwujud) adalah mencakup penampilan fisik, peralatan, personal, dan media komunikasi. Indikator variabel ini adalah:

a. Pengaturan dan penataan ruangan yang nyaman.

b. Peralatan dan fasilitas fisik yang dimiliki memadai.

c. Kondisi lingkungan atau gedung nyaman dan bersih.

d. Akses tempat yang mudah dijangkau.

\section{METODE ANALISIS DATA}

Dalam menganalisis data penelitian ini, penulis menggunakan emapat metode, yaitu:

1) Uji Validitas

Validitas atau tingkat ketepatan, kejituan atau keakuratan adalah kemampuan suatau alat ukur untuk mengukur apa yang seharusnya diukur. Validitas menunjukan sejauh mana skor/nilai ukuran yang diperoleh benar-benar menyatakan hasil pengukuran/pengamatan yang ingin diukur. Validitas pada umumnya dipermasalahkan berkaitan dengan hasil pengukuran psikologis atau non fisik. Berkaitan dengan karakteristik psikologis, hasil pengukuran yang diperoleh sebenarnya diharapkan dapat menggambarkan atau memberikan skor/nilai suatu karakteristik lain yang menjadi perhatian utama. Ukuran validitas yang digunakan adalah dengan korelasi produk momen yang memperoleh hasil bahw akeseluruhan item pertanyaan adalah valid. Kuesioner dikatakan valid jika nilai signifikasi kurang dari 0,05 (Ghozali, 2005).

2) Uji Reliabilitas

Menurut Umar (2004), reliabilitas istilah yang dipakai untuk menunjukan sejauh mana suatu hasil pengukuran relatif konsisten apabila alat ukur kita berulang kali. Suatu instrument adalah reliable sebagai alat pengumpul data apabila memberikan hasil ukuran yang sama terhadap suatu gejala pada waktu yang berlainan.

3) Analisis Data Deskriptif

Analisis ini digunakan untuk menggambarkan tentang ringkasan data-data penelitian seperti mean.

4) Uji Beda T-Test 
Untuk pembuktian hipotesis dilakukan dengan T-Test atau T-Score. Alasan peneliti mengguanakan T-Test dalam menganalisa data adalah karena T-Test pada prinsipnya adalah suatu teknik statistik untuk menguji hipotesis tentang ada tidaknya perbedaan yang signifikan antara dua kelompok sampel dengan jalan perbedaan mean-meanya. Mencari nilai $\mathrm{T}$ uji sampel berpasangan dengan alat bantu software SPSS For Windows 15.0.

5) Uji Varian (Uji F)

Menurut Sugiyono (2008:197), uji varian digunakan untuk mengetahui apakah perbedaan varian populasi asalah sama atau tidak. Uji ini dilakukan sebagai prasyarat dalam analisis independent sample t test. Asumsi yang mendasari dalam analisis varian independent sample t test adalah varian dari populasi adalah sama atau berbeda. Uji varian dilakukan dengan menggunakan uji Fisher pada taraf signifikasi 0,05.

\section{HASIL PENELITIAN DAN PEMBAHASAN}

\section{A. Respon Rate}

Berdasrkan jumlah lembar kuesioner yang disebarkan kepad aresponden penelitian yaitu sebanyak 200 lembar, kuesioner disebarkan dengan metode proposive sampling yaitu dari setiap strata akan diambil sampel dalam proposi tertentu, tergantung pada ukuran (besar kecilnya) populasi masing-masing strata. Menurut Guliford dalam Lutfi (2000) semakin banyak sampel (makin besar nilai $\mathrm{n}=$ banyaknya elemen sampel) akan memberikan hasil yang lebih akurat. Dari jumlah tersebut seluruh kuesioner dijawab dan dikembalikan, dan setelah dilakukan pengecekan jawaban pada kuesioner seluruhnya dijawab secara lengkap sehingga memenuhi syarat untuk diolah. Dengan demikian respon rate kuesioner yang layak untuk dianalisis sebanyak 200 responden. Perincian respon rate kuesioner di sajikan pada tabel sebagai berikut:

Tabel respon responden terhadap kuesioner (respon rate)

\begin{tabular}{|c|l|c|c|}
\hline No & \multicolumn{1}{|c|}{ Perincian } & Jumlah & $\begin{array}{c}\text { Presentase } \\
(\%)\end{array}$ \\
\hline 1 & Kuesioner yang disebarkan & 200 & 100,0 \\
\hline 2 & Kuesioner yang tidak kembali & 0 & 0,0 \\
\hline 3 & $\begin{array}{l}\text { Kuesioner yang kembali (respon } \\
\text { rate) }\end{array}$ & 200 & 100,0 \\
\hline 4 & Kuesioner yang tidak layak & 0 & 0,0 \\
\hline 5 & Kuesioner yang layak dianalisis & 200 & 100,0 \\
\hline
\end{tabular}

Sumber : Data primer diolah, 2014

\section{B. Gambaran Umum Responden}

Dari 200 responden penelitian dikelompokan dalam beberapa kategori yaitu umur, jenis kelamin, dan pekerjaan. Berdasarkan hasil penelitian diketahui bahwa identitas responden dapat dilihat seperti yan tersaji pada table berikut:

Tabel Deskripsi Responden

\begin{tabular}{|c|c|c|c|}
\hline No & Karakteristik & Jumlah & $\begin{array}{c}\text { Presentase } \\
(\%)\end{array}$ \\
\hline 1 & Usia (tahun) & 134 & 67 \\
& $15-25$ & 31 & 15,5 \\
& $26-35$ & 27 & 13,5 \\
& $36-45$ & 8 & 4 \\
\hline
\end{tabular}




\begin{tabular}{|c|c|c|c|}
\hline 2 & $\begin{array}{l}\text { Jenis Kelamin } \\
\qquad \begin{array}{l}\text { Laki-laki } \\
\text { Perempuan }\end{array}\end{array}$ & $\begin{array}{c}82 \\
118\end{array}$ & $\begin{array}{l}41 \\
59\end{array}$ \\
\hline \multirow[t]{10}{*}{3} & Pekerjaan & & \\
\hline & Pelajar & 66 & 33 \\
\hline & Mahasiswa & 67 & 33,5 \\
\hline & IRT & 26 & 13 \\
\hline & PNS & 15 & 7,5 \\
\hline & Wiraswasta & 12 & 6 \\
\hline & Karyawan & 10 & 5 \\
\hline & Pensiun & 1 & 0,5 \\
\hline & Polisi & 1 & 0,5 \\
\hline & Pengangguran & 2 & 1 \\
\hline
\end{tabular}

Berdasarkan table diketahui bahwa mayoritas responden berusia 15-25 tahun yaitu sebanyak 134 responden (67\%) dan hanya 8 responden yang berusia 46-50 tahun. Hal ini mengindikasikan bahwa mayoritas konsumen Alfamart dan Indomart di wilayah Dukuhwaluh yang menjadi responden berusia 15-25 tahun. Sebagian besar jenis kelamin responden adalah perempuan yaitu sebanyak 188 responden (59\%). Hal ini mengindikasikan konsumen Alfamart dan Indomaret di wilayah Dukuhwaluh lebih banyak perempuan daripada laik-laki. Pekerjaan responden paling banyak adalah sebagai mahasiswa sebanyak 67 orang (33,5\%), hal ini mengindikasikan dalam penelitian ini sebagian besar responden adalah mahasiswa, dikarenakan letak Indomaret dan Alfamart berada pada lingkungan universitas.

Penelitian ini bertujuan untuk menganalisis bentuk perbedaan kepuasan konsumen atas pelayanan minimarket Indomaret dan Alfamart di wilayah Dukuhwaluh yang dijelaskan per dimensi. Setelah dilakukan pengujian dapat diperoleh hasil sebagai berikut:

1. Kepuasan Konsumen

Kepuasan konsumen adalah perasaan seseorang yang puas atau sebaliknya setelah membandingkan antara kenyataan dan harapan yang diterima dari sebuah produk atau jasa (Kolter 2000:36). Hasil penelitian ini membuktikan bahw aterdapat perbedaan signifikan kepuasan konsumen antara minimarket Indomaret dan Alfamart di eilayah Dukuhwaluh. Berdasarkan hasil uji t diperoleh t hitung sebesar 16,210 dengan probabilitas signifikasi 0,000 (two tailed) yang lebih kecil dari 0,05 .

2. Kehandalan

Kemampuan perusahaan untuk memberikan pelayanan sesuai dengan yang dijanjikan secara akurat dan terpercaya. Kinerja harus sesuai dengan harapan pelanggan yang berarti ketepatan waktu, pelayanan yang sama untuk semua pelanggan tanpa kesalahan, sikap yang simpatik, dan dengan akurasi yang tinggi, Parasuraman (Lupiyoadi, 2001). Hasil penelitian ini membuktikan bahwa kehandalan pada minimarket Indomaret tidak berbeda dengan kehandalan pada minimarket Alfamart di wilayah Dukuhwaluh. Hal ini dikarenakan hasil uji $\mathrm{t}$ diperoleh $\mathrm{t}$ hitung sebebsar 0,895 dengan probabilitas signifikasi 0,372 (two tailed) yang lebih besar dari 0,05 .

3. Ketanggapan

Suatu kemampuan untuk membantu dan memberikan pelayanan yang cepat (responsive) dan tepat kepad apelanggan denganpenyampaian informasi yang jelas. Membiarkan konsumen menunggu tanpa adanya suatu alasan yang jelas menyebabkan persepsi yang negative dalam kualitas pelayanan, Parasuraman (Lupiyoadi, 2001). Hasil penelitian ini membuktikan bahwa terdapat perbedaan signifikan dari segi ketanggapan anatara minimarket Indomaret dan Alfamart di wilayah Dukuhwaluh. Berdasarkan hasil uji t 
diperoleh t hitung sebesar -12,937 dengan probabilitas signifikansi 0,000 (two tailed) yang lebih kecil dari 0,05 .

4. Jaminan

Pengetahuan, kesopan santuanan dan kemampuan para pegaeai perusahaan untuk menumbuhkan rasa percaya para pelanggan kepad aperusahaan. Terdiri dari beberapa komponen, antara lain komunikasi, kredibilitas, keamanan, kompetisi dan sopan santun, Parasuraman (Lupiyoadi,2001). Hasil penelitian ini membuktikan bahwa jaminan minimarket Indomaret tidak berbeda dengan jaminan pada minimarket Alfamart di wilayah Dukuhwaluh. Hal ini dikarenakan hasil uji t diperoleh $\mathrm{t}$ hitung sebebsar 0,187 dengan probabilitas signifikasi 0,852 (two tailed) yang lebih besar dari 0,05.

5. Perhatian

Memberikan perhatian yang tulus dan bersifat individual atau pribadi yang diberikan kepada para pelanggan dengan berupaya memahami keinginan konsumen, dimana suatu perusahaan diharapkan memiliki pengertian dan pengetahuan tentang pelanggan, memahami kebutuhan pelanggan secara spesifik, serta memiliki waktu pengoperasian bagi pelanggan, Parasuraman (Lupioadi, 2001). Hasil penelitian ini membuktikan bahwa perhatian pada minimarket Indomaret tidak berbeda dengan perhatian pada minimarket Alfamart di wilayah Dukuhwaluh. Hal ini dikarenakan hasil uji t diperoleh t hitung sebebsar 0,405 dengan probabilitas signifikasi 0,686 (two tailed) yang lebih besar dari 0,05.

6. Wujud

Kemampuan suatu perusahaan dalam menunjukan eksistensinya kepada pihak eksternal. Penampilan dan kemampuan sarana dan prasarana fisik perusahaan dan keadaan lingkungan sekitarnya adalah bukti nyata daripelayanan yang diberikan oleh pemberi jasa. Kinerja harus sesuai dengan harapan pelanggann yang berarti ketepatan waktu pelayanan yang sama untuk semua pelanggan, Parasuraman (Lupiyoadi, 2001). Hasil penelitian ini membuktikan bahwa wujud pada minimarket Indomaret tidak berbeda dengan wujud pada minimarket Alfamart di wilayah Dukuhwaluh. Hal ini dikarenakan hasil uji t diperoleh $t$ hitung sebebsar $-0,785$ dengan probabilitas signifikasi 0,433 (two tailed) yang lebih besar dari 0,05.

\section{KESIMPULAN DAN SARAN}

\section{A. Kesimpulan}

Berdasarkan pengolahan data danhasil analisis yang mengacu pada masalah dan tujuan penelitian, maka dapat dirumuskan kesimpulan penelitian sebagai berikut:

1. Hipotesis pertama yang menyatakan bahwa ada perbedaan signifikan kepuasan konsumen antara minimarket Indomaret dan Alfamart di wilayah Dukuhwaluh, diterima. Hal ini ditunjukan dengan nilai t hitung 16,210 dengan probabilitas signifikasi 0,000 (two tailed) yang lebih kecil dari 0,05. Artinya terdapat perbedaan signifikasi kepuasan konsumen antara minimarket Indomaret dan Alfamart di wilayah Dukuhwaluh. Kepuasan yang diperoleh konsumen minimarket Indomaret berbeda dengan kepuasan yang diperoleh minimarket Alfamart.

2. Hipotesis kedua yang menyatakan bahwa ada perbedaan signifikan dari segi kehandalan antara minimarket Indomaret dengan minimarket Alfamart, ditolak. Hal ini ditunjukan dengan nilai t hitung 0,895 dengan probabilitas signifikasi 0,372 (two tailed) yang lebih besar dari 0,05. Artinya tidak terdapat perbedaan signifikan dari segi kehandalan antara minimarket Indomaret dengan minimarket Alfamart. Kehandalan yang diterapkan oleh minimarket Indomaret relatif sama dengan kehandalan yang diterapakan oleh minimarket Alfamart.

3. Hipotesis ketiga yang menyatakan bahwa ada perbedaan signifikan dari segi ketanggapan antara minimarket Indomaret dan Alfamart di wilayah Dukuhwaluh, diterima. Hal ini ditunjukan dengan nilai t hitung 12,973 dengan probabilitas signifikasi 
0,00 (two tailed) yang lebih kecil dari 0,05. Artinya terdapat perbedaan signifikan dari segi ketanggapan antara minimarket Indomaret dan Alfamart di wilayah Dukuhwaluh. Ketanggapan yang ditetapkan oleh minimarket Indomaret dan Alfamart di wilayah Dukuhwaluh. Ketanggapan yang diterapkan oleh minimarket Indomaret berbeda dengan ketanggapan yang ditertapkan oleh minimarket Alfamart.

4. Hipotesis kekempat yang menyatakan bahwa ada perbedaan signifikan dari segi jaminan antara minimarket Indomaret dengan minimarket Alfamart, ditolak. Hal ini ditunjukan dengan nilai t hitung 0,187 dengan probabilitas signifikasi 0,852 (two tailed) yang lebih besar dari 0,05. Artinya tidak terdapat perbedaan signifikan dari segi jaminan antara minimarket Indomaret dengan minimarket Alfamart. Jaminana yang diterapkan oleh minimarket Indomaret relatif sama dengan jaminan yang diterapkan oleh minimarket Alfamart.

5. Hipotesis kelima yang menyatakan bahwa ada perbedaan signifikan dari segi perhatian antara minimarket Indomaret dengan minimarket Alfamart, ditolak. Hal ini ditunjukan dengan nilai t hitung 0,405 dengan probabilitas signifikasi 0,686 (two tailed) yang lebih besar dari 0,05 . Artinya tidak terdapat perbedaan signifikan dari segi perhatian antara minimarket Indomaret dengan minimarket Alfamart. Perhatian yang diterapkan oleh minimarket Indomaret relatif sama dengan jaminana yang diterapkan oleh minimarket Alfamart.

6. Hipotesis keenam yang menyatakan bahwa ada perbedaan signifikan dari segi wujud antara minimarket Indomaret dengan minimarket Alfamart, ditolak. Hal ini ditunjukan dengan nilai t hitung 0,-0,785 dengan probabilitas signifikasi 0,433 (two tailed) yang lebih besar dari 0,05 . Artinya tidak terdapat perbedaan signifikan dari segi wujud antara minimarket Indomaret dengan minimarket Alfamart. Wujud atau bukti fisisk yang diterapkan oleh minimarket Indomaret relatif sama dengan jaminana yang diterapkan oleh minimarket Alfamart.

\section{B. Saran}

Berdasarkan kesimpulan diatas, maka saran yang diajaukan penulis adalah sebagai berikut:

1. Manajemen minimarket Indomaret

- Hasil yang didapatkan oleh konsumen minimarket Indomaret di wilayah Dukuhwaluh telah sesuai dengan harapan yang mereka inginkan sehingga kepuasan konsumen meningkat, jadi perlu di pertahankan agar konsumen tetap merasa puas.

- Penelitian ini dapat dijadikan salah satu bahan pertimbangan dalam mempertahankan kehandalan yang sudah diterapkan oleh minimarket Indomaret di wilayah Dukuhwaluh.

- Ketanggapan yang diterapkan oleh pihak minimarker Indomaret di wilayah Dukuhwaluh masih dibawah pesaing, jadi dari pihak minimarket Indomaret harus lebih tanggap dalam melayani konsumen.

- Penelitian ini dapat dijadikan salah satu bahan pertimbangan dalam mempertahankan jaminan yang sudah diterapkan oleh minimarket Indomaret di wilayah Dukuhwaluh untuk konsumen.

- Penelitian ini dapat dijadikan salah satu bahan pertimbangan dalam mempertahankan perhatian minimarket Indomaret di wilayah Dukuhwaluh yang telah diberikan kepada konsumen.

- Penelitian ini dapat dijadikan salah satu bahan pertimbangan dalam mempertahankan eksistensi dalam bentuk wujud yang telah diterapkan oleh minimarket Indomaret di wilayah Dukuhwaluh yang telah diberikan untuk konsumen. 
2. Manajemen minimarket Alfamart

- Kepuasan yang didapatkan oleh konsumen minimarket Alfamart masih dibawah pesaing jadi perlu adanya peningkatan dalam memenuhi kepuasan konsumen.

- Penelitian ini dapat dijadikan salah satu bahan pertimbangan dalam mempertahankan kehandalan yang sudah diterapkan oleh minimarket Alfamart di wilayah Dukuhwaluh.

- Ketanggapan pihakminimarket Alfamart di wilayah Dukuhwaluh dalam melayani konsumen telah menimbulkan rasa puasa pada konsumen, jadi ketanggapan yang diberikan pihak minimarket Alfamart harus tetap dipertahankan.

- Penelitian ini dapat dijadikan salah satu bahan pertimbangan dalam mempertahankan jaminan yang sudah diterapkan oleh minimarket Alfamart di wilayah Dukuhwaluh untuk konsumen.

- Penelitian ini dapat dijadikan salah satu bahan pertimbangan dalam mempertahankan perhatian yang sudah diterapkan oleh minimarket Alfamart di wilayah Dukuhwaluh untuk konsumen.

- Penelitian ini dapat dijadikan salah satu bahan pertimbangan dalam mempertahankan eksistensi dalam bentuk wujud yang telah diterapkan oleh minimarket Alfamart di wilayah Dukuhwaluh untuk konsumen.

\section{DAFTAR PUSTAKA}

Arikunto, Suharsimi. Manajemen Penelitian. Rineka Cipta: Jakarta

Dwiwinarsih, Rina.2009. Analisis Tingkat Kepuasan Konsumen Terhadap Pelayanan Bakmi Aisy di Depok. Jurnal Ekonomi Manajemen

Djarwanto. 1999. Statistik nonparametik. BPFE: Yogyakarta

Engel, James, R.D. Blackwell \&P.W. Minlard.1997. Perilaku Konsumen Jilid 1 Edisi Keenam. Binarupa Aksara: Jakarta

Fomel, C. Jhonson, MD Anderson, EW Cha, and Bryant BE. 1996. "The American

Customer Satisfaction Index: Nature, Purpose, and Findings”. Journal of Marketing, vol.60

Ghozali, Imam. 2005. Aplikasi Multivariate dengan Program SPSS. Badan Penenrbit Universitas Diponegoro:Semarang

Kolter, Philip.200. Manajemen Pemasaran di Indonesia. Salemba Empat: Jakarta

Liu, MC. 2005. "The Dimnensionaland Hierarchical Structure of Percieved Quality and Customer Statisfaction”. International Journal of Management, vol 22, no.3

Lupyoadi, Rambat.2001. Manajemen Pemasaran Jasa. Edisi Pertama. Selemba Empat: Jakarta

Mulyono, Bayu Hadyanto dkk.2008. Analisis Pengaruh Kualitas Produk dan Kualitas Layanan Terhadap Kepuasan Konsumen ( Studi Kasus Pada Peumahan Puri Mediterania Semarang)

Munawaroh, Munijati.2000. Analisis Pengaruh Kualitas Jasa Terhadap Konsumen Pada Industri Pendidikan di Yogyakarta. Jurnal Siasat Bisnis Edisi no.5 vol.2

Parasuraman, A., Berry, Leonard L, and Zeithaml, Vaarie A. 1985. " A Conceptual Model of Service Quality and its Implicatons for Fiture Research”. Journal of Marketing, Vol; 49 (fall),pp.42-50

Payne, Adrian.2000. Pemasaran Jasa (The Essence of Service Marketing), Tejemahan Fandy Tjiptono, edisi pertama, cetakan pertama, penerbit Andi: Yogyakarta.

----------, 1988. “SERQUAL: A-Multiple-Item Scale for Measuring Cosnsumer Preceptions of Service Quality”. Journal of Retailing, Vol;64(Spring). Pp.12-24

Sugiyono.2000. Metode Penelitian Bisnis. Alfabeta: Bandung

Sumarwan, Ujang.2003. Perilaku Konsumen (Teori dan Penerapanya dalam Pemasaran). Ghalia Indonesia: Jakarta 
Supranto, J.2001. Pengukuran Tingkat Kepuasan Pelanggan. Edisi Baru. PT.Rineka Cipta: Jakarta

Tjiptono, F., dan Chandra, G.2005. Service Quality and Satisfaction. Andi Yogyakarta

--------. 1997. "Kualitas Jasa dan Customer Value” dan "Kepuasan Pelanggan, Loyalitas Pelanggan dan Customer Relationship" Dalam Pemasaran Jasa. Bantumedia Publishing: Jawa Timur

Umar, Husein.2003. Pokok-Pokok Materi Statistik: Statistik Interaktif. Bumi Aksara: Jakarta ---------2002. Riset Pemasaran \& Perilaku Konsumen. PT Gradmedia Pustaka Utama: Jakarta

---------.2003. Metode Riset Perilaku Konsumen Jasa. Ghalia Indonesia: Jakarta 